\title{
KARAKTERISASI DAMAR DARI PESISIR SELATAN DAN APLIKASINYA UNTUK PEMBUATAN PERNIS
}

\author{
Anwar Kasim ${ }^{1}$, Deivy Andhika Permata ${ }^{1^{*}}$, dan Yefsi Malrianti ${ }^{1}$ \\ ${ }^{1}$ Jurusan Teknologi Industri Pertanian, Fakultas Teknologi Pertanian, Universitas Andalas, Padang \\ Email: deivyandhikapermata@ae.unand.ac.id
}

\begin{abstract}
ABSTRAK
Damar merupakan resin resin alami yang dihasilkan oleh tanaman dari famili Dipterocarpaceae dan Burseraceae. Sumatera Barat adalah satu propinsi penghasil damar yang penting di Indonesia dengan sentra produksi Kabupaten Pesisir Selatan. Pemanfaatan damar di Indonesia sebagian kecil untuk memenuhi kebutuhan pembatik dalam negeri dan sebagian besar diekspor. Padahal damar dapat dijadikan sebagai bahan baku utama pernis yang dapat digunakan pada industri mebel dan bagian tertentu bangunan. Penelitian ini bertujuan untuk mengkaji karakteristik damar yang diperoleh dari Kabupaten Pesisir Selatan dan menentukan komposisi yang tepat pada pembuatan pernis yang memanfaatkan damar tersebut. Selain damar juga digunakan terpentin dan minyak kemiri sebagai bahan penyusun pernis. Hasil penelitian memperlihatkan bahwa di Pesisir Selatan didapatkan jenis damar mata kucing dan damar batu. Karakteristik damar mata kucing yang didapatkan antara lain warna kuning bening, titik leleh $71{ }^{\circ} \mathrm{C}$, densiti $0,68 \mathrm{~g} / \mathrm{cm}$ dan kehilangan berat suhu $105{ }^{\circ} \mathrm{C} 18 \mathrm{jam}$ $0,84 \%$. Komposisi terpilih pernis yang dihasilkan dengan waktu pengeringan yang sama dengan pernis komersil adalah $23 \%$ damar, $54 \%$ terpentin dan $23 \%$ minyak kemiri.
\end{abstract}

Kata kunci-damar; kemiri; pernis; terpentin

\section{PENDAHULUAN}

Damar merupakan salah satu resin alami yang dihasilkan oleh tanaman dari famili Dipterocarpaceae (marga Shorea, Hopea, Balanocarpus, dan Vateria) dan Burseraceae (marga Canarium) (BBSRC, 2004; Kuspradini et al., 2016). Pohon penghasil damar tumbuh baik di Pulau Sumatera, Kalimantan, Sulawesi, dan Maluku (Kuspradini et al., 2016). Berdasarkan data BPS, Sumatera Barat merupakan salah satu Propinsi penghasil damar utama di Indonesia dengan jumlah produksi $31756 \mathrm{~kg}$ di tahun 2017 (BPS, 2020). Dari total produksi damar Sumatera Barat tersebut $61 \%$ diantaranya untuk tujuan ekspor. Kabupaten penghasil damar utamanya adalah Pesisir Selatan dan diikuti oleh Kabupaten 50 Kota, Padang Pariaman, Sawahlunto dan Tanah Datar (Karyono et al, 1996). Perbedaan pohon penghasil damar dan tempat tumbuhnya tentu mempengaruhi karakteristik dari damar itu sendiri, sehingga apabila diaplikasikan untuk keperluan lain maka perlu diketahui karakteristiknya terlebih dahulu.

Damar banyak digunakan pada berbagai industri misalnya sebagai bahan emulsi (campuran) pewarna, pembuatan cat, lilin, plastik, bahan isolator, bahan campuran pernis, bahan pengisi kertas, dan industri pangan serta bahan obat-obatan (BBSRC, 2004; Abdulmalik et al, 2016; Kuspradini et al., 2016). Selain kegunaan di atas damar juga dapat dipergunakan dalam bahan perekat kapal dalam pembuatan kapal boat, sedangkan bila dicampur dengan kusen dapat dipakai sebagai bahan pengawet (Arianti et al., 2018; Kuspradini et al., 2016). Menurut Kartika dan Pratiwi (2018) secara tradisional, damar digunakan sebagai bahan bakar obor penerang, penambal perahu, dan kerajinan tangan. Damar dapat digunakan sebagai lilin pengeras pada industri semir, kertas karbon, pita mesin ketik, industri vernis, dan bantalan objek mikroskopik.

Menurut Edriana et al (2018), pada pembuatan pernis dapat menggunakan formulasi yang memanfaatkan damar mata kucing dengan pelarut toluen teknis dan berbagai bahan pembantu lainnya. Hasil penelitian menunjukkan bahwa pernis dari bahan baku damar yang berkualitas rendah dengan formula campuran $65 \%$ larutan damar, 25\% alkyd sintetis, $8.8 \%$ minyak tanah, $0.3 \%$ kobal kering, dan $0.9 \%$ kalsium kering menghasilkan kualitas pernis yang baik. Pernis yang dihasilkan memerlukan waktu pengeringan selama $3 \mathrm{jam}$. Dahlian et al (2003) menjelaskan bahwa pernis terdiri dari campuran minyak mudah kering, resin dan pelarut. Dari studi yang dilakukan banyak ditemukan variasi penggunaan bahan penyusun pada pembuatan pernis, salah satu formulasi yang digunakan $1 / 3$ minyak linseed, 1/3 pelarut dan 1/3 resin. Berdasarkan hal ini diperlukan suatu kajian untuk 
mengetahui komposisi yang tepat dalam pembuatan pernis. Sebelum diaplikasikan pada pernis perlu diketahui dahulu karakteristik damar yang akan digunakan. Penelitian ini bertujuan untuk mengkaji karakteristik damar yang diperoleh dari Kabupaten Pesisir Selatan dan menentukan komposisi yang tepat pada pembuatan pernis yang memanfaatkan damar tersebut.

\section{METODOLOGI PENELITIAN}

\section{A. Bahan dan Alat Penelitian}

Bahan utama yang digunakan pada penelitian ini adalah damar mata kucing dan damar batu yang berasal dari Pesisir Selatan, bahan campuran pernis yaitu minyak kemiri, terpentin, dan bahan kimia untuk analisis sifat kimia damar. Peralatan yang digunakan meliputi peralatan pengamatan sifat fisika, alat GC-MS untuk analisis komponen kimia damar. Alat laboratorium lainnya yang digunakan dalam penelitian ini meliputi timbangan analitik, sentrifuge, oven vacuum, alat destilasi, tanur, dan alat gelas.

\section{B. Prosedur Penelitian dan Analisis Data}

Penelitian ini bersifat eksploratif dengan mengamati karakteristik bahan baku dan pernis yang dihasilkan, pengamatan dilakukan sebanyak 3 kali ulangan. Pelaksanaan penelitian disusun seperti prosedur dibawah ini atau dapat dilihat pada Gambar 1:

a. Preparasi damar

Pengadaan bahan baku, yaitu damar mata kucing dan damar batu yang diperoleh dari pengepul di Pesisir Selatan. Damar yang diperoleh disortasi. Damar terpilih selanjutnya diperkecil ukurannya dengan cara digiling dan di ayak. Damar yang lolos ayakan 60 mesh diambil untuk keperluan penelitian. Selanjutnya dilakukan pengamatan sesuai SNI 2900-1-2012, meliputi warna, bau, densiti, kelarutan, titik lebur dan komposisi kimia

b. Preparasi kemiri

Pengadaan bahan baku, yaitu daging buah kemiri yang dipeoleh dari Sawahlunto. Daging buah kemiri disortasi. Dilakukan pengecilan ukuran pada daging buah kemiri terpilih hingga lolos ayakan 60 mesh. Dilakukan ekstraksi minyak kemiri, selanjutnya dilakukan pengamatan terhadap minyak kemiri sesuai dengan SNI 01-4462-1998, meliputi warna, bau, bobot jenis, viskositas dan indek bias

c. Preparasi sampel uji kayu

Pengadaan sampel uji berupa kayu meranti dengan ukuran $10 \mathrm{~cm}$ x $5 \mathrm{~cm} \times 1 \mathrm{~cm}$. Kayu diperlakukan secara sama, dibersihkan agar permukaan terlihat jelas saat pengamatan.

d. Pengadaan dan pengamatan terhadap terpentin komersil

Terpentin komersil yang digunakan adalah terpentin dengan merek dagang High Gloss Thinner. Selanjutnya dilakukan pengamatan sifat terpentin sesuai SNI 7633:2011, meliputi viskositas, bobot jenis, transparansi, indeks bias

e. Pengadaan dan pengamatan terhadap pernis

Pembuatan pernis dilakukan dengan beberapa variabel perbandingan pada ketiga bahan. Selanjutnya dilakukan pengamatan sifat pernis sesuai SNI. Pernis diaplikasi pada kayu yang telah disiapkan dan dilakukan pengamatan hasil pernis sesuai SNI ISO 12944-6:2012, yaitu warna, bau, densiti, dan viskositas. Sedangkan pada kayu yang dilapisi pernis dilakukan pengamatan kilap dan lama mengering pernis. 


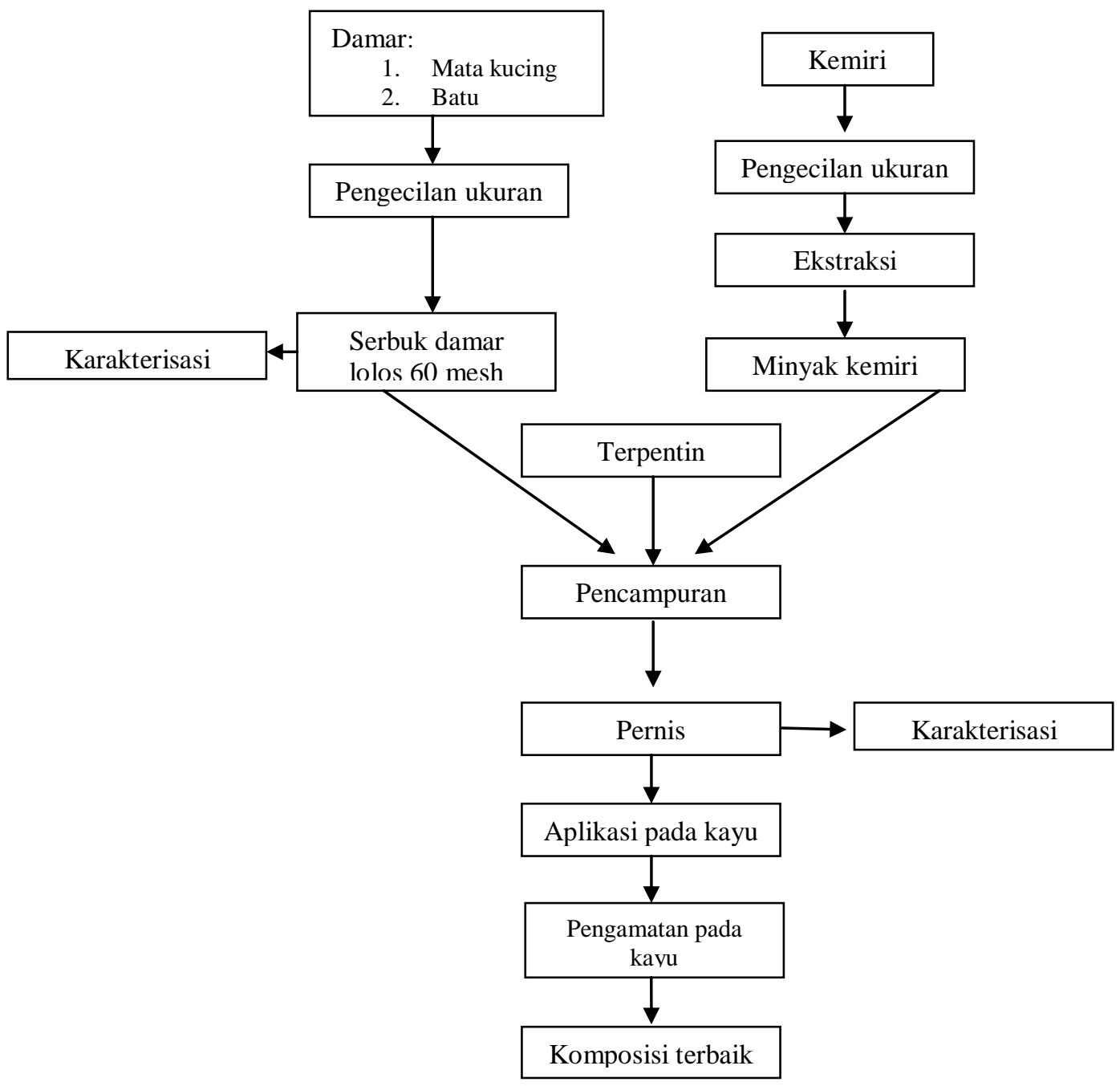

Gambar 1. Diagram Alir Penelitian

\section{HASIL DAN PEMBAHASAN}

\section{A. Karakteristik Damar}

Damar yang berasal dari Pesisir Selatan (Pessel) dikumpulkan oleh petani dari hutan tanah ulayat dan lahan negara seperti Taman Nasional Kerinci Seblat dan Cagar Alam Tarusan. Jenis damar yang dikumpulkan yaitu damar mata kucing dan damar batu seperti pada Gambar 2a dan 2b. Pohon yang banyak penghasil damar mata kucing yaitu jenis meranti. Damar batu dikumpulkan dari tanah dan biasanya ada bahagian yang terlihat di permukaan tanah. Damar batu dicari sampai jauh masuk ke hutan.
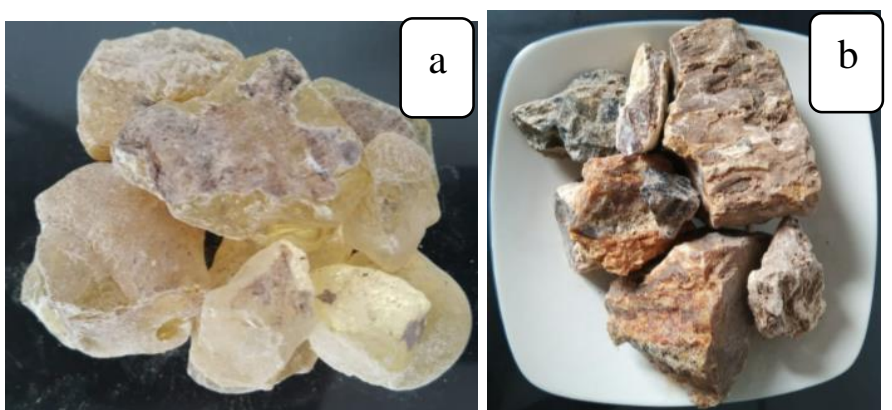

Gambar 2. (a) Damar mata kucing, (b) Damar batu 
Pengumpulan damar mata kucing dan damar batu dilakukan oleh masyarakat rata-rata 1 kali seminggu dan kadang-kadang sekali sebulan. Produksi damar tergantung pada banyaknya damar yang dikumpulkan, namun jika harga mahal masyarakat lebih giat untuk mengumpulkannya dan juga dikumpulkan sesuai pesanan. Petani akan banyak mengumpulkan damar jika harga relatif mahal seperti Rp 10.000/kg. Pengumpulan damar oleh penduduk sekitar hutan hanya sebagai sumber pendapatan tambahan. Damar yang telah dikumpulkan baik damar mata kucing maupun damar batu dilakukan pembersihan secukupnya. Hanya sedikit sekali damar yang dimanfaatkan oleh pengumpul atau masyarakat sekitar hutan. Penggunaan secara tradisional adalah sebagai bahan perekat untuk penangkap burung, perekat pada kapal dan penghidupkan api.

Mengingat damar batu pada umumnya tercampur dengan bahan bukan damar relatif banyak maka untuk pelaksanaan penelitian selanjutnya difokuskan untuk damar mata kucing. Damar yang digunakan dikumpulkan dari kawasan Mande, Surantiah dan Tapan. Hasil karakterisasi beberapa sifat dapat dilihat pada Tabel 1.

Tabel 1. Karakteristik Damar Mata Kucing

\begin{tabular}{ll}
\hline \multicolumn{1}{c}{ Parameter } & \multicolumn{1}{c}{ Nilai/Keterangan } \\
\hline Warna & Kuning bening \\
Bau & Khas damar \\
Bentuk & Butiran \\
Ukuran & Variatif dengan diamater $1-4 \mathrm{~cm}$ \\
Titik leleh & $71^{\circ} \mathrm{C}$ \\
Density & $0,68 \mathrm{~g} / \mathrm{cm}^{3}$ \\
Kehilangan berat suhu $105^{\circ} \mathrm{C} 18 \mathrm{jam}$ & $0,84 \%$ \\
\hline
\end{tabular}

\section{B. Komposisi Kimia Damar dengan GC-MS}

Metode preparasi sampel mengacu kepada metodeet al., (2018), tepung damar dilarutkan dalam toluen dan disaring menggunakan saringan $250 \mu \mathrm{m}$. Sistem kromatografi gas seri Shimadzu GCMSQP-2010 plus (Shimadzu, Kyoto, Jepang) mengacu kepada metode Kasim et al., (2019) digunakan untuk melakukan analisis. Kolom Gas Chromatographic digunakan untuk pemisahan matriks dalam sampel dengan kolom DB-5-Resin (30 m 0,25 mm 0,25 m) dari Agilent (Agilent Technologies, Santa Clara, CA, USA). Suhu injector yang digunakan yaitu $250^{\circ} \mathrm{C}$, volume injeksi $2 \mu \mathrm{L}$. Gas pembawa adalah helium pada aliran $1 \mathrm{ml} / \mathrm{menit}$. Suhu pada jalur injeksi ditetapkan pada $300^{\circ} \mathrm{C}$. Suhu awalnya pada $40^{\circ} \mathrm{C}$ selama 2 menit, kemudian meningkat dengan suhu $10^{\circ} \mathrm{C} /$ menit sampai $300^{\circ} \mathrm{C}$ dan konstan pada suhu $300^{\circ} \mathrm{C}$ selama 3 menit. Kromatogram diperoleh dalam full scan mode (m/z 35-500). Identifikasi senyawa dilakukan menggunakan mass spectral libraries NIST47 dan Wiley Registry TM ${ }^{7 t h}$ edition. Hasil analisis diperlihatkan pada Tabel 2 dimana ditampilkan 10 senyawa terbanyak berdasarkan persentase luas peaknya pada spektrum GC-MS.

Tabel 2. Senyawa Kimia Persentase 10 Tertinggi pada Damar Mata Kucing Asal Pesisir Selatan

\begin{tabular}{cl}
\hline No & \multicolumn{1}{c}{ Senyawa Kimia } \\
\hline 1 & Oleic acid \\
2 & Hexadeconic acid (CAS) Palmitic acid \\
3 & Copaene \\
4 & Octadeconic acid (CAS) Stearic acid \\
5 & 9,12-octadeconic acid (CAS) Palmitic acid \\
6 & Hexadeconic acid \\
7 & 9-Octadecenoic acid (Z) \\
8 & Cyclohexane \\
9 & Trans-Geraniol \\
10 & Bezyl alcohol \\
\hline
\end{tabular}

\section{Kelarutan Damar dalam Beberapa Pelarut}

Pada pembuatan pernis perlu diketahui sifat kelarutan resin yang digunakan dalam pelarut sebagai komponen pembuatan pernis. Penggunaan pelarut benzene dan toluene juga telah dilakukan 
Wiyono dan Silitonga (2001), dengan hasil persentase kelarutan damar dalam pelarut benzene 84,8 \% dan dalam pelarut toluene $74,4 \%$. Wiyono (1995) juga melakukan penelitian yang sama terhadap damar dan mendapatkan hasil yang berbeda. Hasil persentase kelarutan pada benzene $81,92 \%$ dan pada toluene $85,68 \%$. Pada Tabel 3 ditampilkan persentase kelarutan damar didalam beberapa pelarut.

Tabel 3. Persentase Kelarutan Damar Mata Kucing pada Beberapa Pelarut

\begin{tabular}{cc}
\hline Pelarut & Persentase kelarutan damar (\%) \\
\hline Heksana & 48,65 \\
Toluen & 99,81 \\
Xylol & 99,94 \\
Butanol & 70,55 \\
Etil asetat & 90,51 \\
Aseton & 62,96 \\
Terpentin & 99,85 \\
\hline
\end{tabular}

\section{Proses Produksi dan Karakteristik Minyak Kemiri}

Sifat minyak kemiri dipengaruhi oleh metode ekstraksi dan mutu bahan bakunya. Minyak kemiri yang diperoleh dengan pengempaan panas berwarna kuning sampai coklat sedangkan dengan pengempaan dingin berwarna kuning pucat. Disamping itu, minyak kemiri memiliki sifat ketidakjenuhan yang tinggi, sehingga dapat digunakan sebagai pengganti minyak biji rami yang dipakai untuk memenuhi kebutuhan minyak mengering dalam berbagai bidang industri (Yusnita et al., 1999).

Proses ekstraksi minyak kemiri dilakukan pada suhu $60^{\circ} \mathrm{C}$ selama 60 menit. Proses produksi minyak kemiri telah dilakukan oleh beberapa peneliti sebelumnya, diantaranya Darmawan (2006), melakukan proses ekstraksi dengan perlakuan pendahuluan berbeda masing-masingnya yaitu dengan cara dioven, dijemur, dan disangrai yang menghasilkan rendemen 35,00\%, 36,13\% dan 33,57\%. Wiyono (1995) juga melakukan ekstraksi minyak kemiri dengan perlakuan pemanasan dan kempa hidroulik menghasilkan rendemen minyak sebesar 52,14\%. Data tentang daging kemiri dan minyak hasil ekstraksi terlihat pada Tabel 4 dan gambar minyak kemiri dapat dilihat pada Gambar 3.

\begin{tabular}{ll} 
Tabel 4. Data Tentang Daging Kemiri dan Minyak Hasil Ekstraksi \\
\multicolumn{1}{c}{ Parameter } & \multicolumn{1}{c}{ Jumlah/Keterangan } \\
\hline Kadar air daging Kemiri & $4,57 \%$ \\
Kadar minyak daging kemiri & $56,99 \%$ \\
Rendemen minyak hasil & $49,13 \%$ \\
kempaan & \\
Kadar air minyak kemiri & $0,07 \%$ \\
Kekentalan minyak kemiri & $26,99 \mathrm{cP}$ \\
Warna minyak kemiri & Kekuningan \\
\hline
\end{tabular}

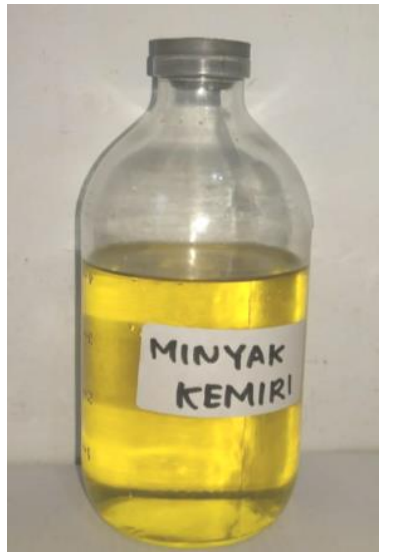

Gambar 3. Minyak Kemiri Hasil Ekstraksi 


\section{E. Karakteristik Terpentin yang Digunakan pada Penelitian}

Terpentin merupakan getah dari pohon Pinus (Pinus merkusii) yang kemudian diolah menjadi terpentin, getah lengket berwarna kuning muda atau coklat yang berbau balsem tersebut diolah dengan cara disuling untuk memisahkan antara minyak terpentin dengan residu lainnya. Pada penyulingan terpentin, getah juga dapat menghasilkan residu berupa minyak atsiri dan juga resin, tergantung dari cara penyulingannya. Di Indonesia sendiri, cara yang biasa digunakan untuk memisahkan minyak terpentin dengan residu lainnya adalah dengan cara disuling.

Proses produksi terpentin juga dilakukan Abdulghani (2002), selain gondorukem proses distilasi terhadap getah pinus juga diperoleh terpentin. Di dalam distilasi, gondorukem merupakan hasil yang tertinggal di dalam tangki distilasi, sedangkan terpentin merupakan uap yang keluar meninggalkan tangki distilasi. Ketika keluar dari tangki destilasi, terpentin berupa uap ini diberikan perlakuan kondensasi, sehingga terjadi perubahan status terpentin dari status gas menjadi status cairan (Suranto, 2018).

Terpentin biasanya digunakan untuk bahan baku industri kosmetik, minyak cat, campuran bahan pelarut, antiseptik, kamper dan farmasi. Terpentin yang digunakan pada penelitian ini adalah terpentin komersil dengan merek dagang High Gloss Thinner. Beberapa sifat terpentin yang diamati ditampilkan pada Tabel 5.

Tabel 5. Karakteristik Terpentin Komersil dengan Merek Dagang High Gloss Thinner

\begin{tabular}{ll}
\hline \multicolumn{1}{c}{ Parameter } & \multicolumn{1}{c}{ Nilai } \\
\hline Kekentalan & $10 \mathrm{cP}$ \\
BJ & $0,6-0,7$ \\
Warna transparan & bening \\
Indeks bias & 0,9 \\
\hline
\end{tabular}

\section{F. Karakteristik Pernis sebagai Pembanding pada Penelitian}

Pernis adalah cairan pemoles kayu yang dibuat dari campuran resin, drying oil, thinner, pelarut, pigmen, bahan pengering, aditif atau bahan-bahan lainnya yang apabila diaplikasikan pada suatu permukaan bahan dapat membentuk lapisan kering, keras dan rekat pada permukaan. Cairan pernis ini berwana bening transparan dan beraroma cukup menyengat (Dahlian et a.l, 2003).

Pernis kayu memiliki keunggulan jika dibandingkan dengan pelitur karena memiliki fungsi lain untuk mempertahankan keawetan material kayu yang dilapisi. Perabot ataupun furnitur yang menggunakan pernis kayu menjadi lebih tahan lama karena pernis kayu membuat serat-serat kayu menjadi lebih kuat sehingga kayu tidak cepat rusak atau lapuk (Dahlian et al., 2003). Pada pelaksanaan penelitian digunakan pernis komersil dengan merek dagang BOYO. Beberapa karakteristik pernis tersebut adalah seperti dicantumkan pada Tabel 6.

Tabel 6. Karakteristik Pernis Komersil Merek BOYO sebagai Pembanding pada Penelitian

\begin{tabular}{ll}
\hline Parameter & Nilai \\
\hline Kekentalan (Ford Cup $\left./ 30^{0} \mathrm{C}\right)$ & $50-60$ detik \\
BJ & $0,94-0,96$ \\
Kadar padatan & $55-60 \%$ \\
Waktu kering: & \\
Sentuh & $15-30$ menit \\
Tekan & $2-3$ jam \\
Keras & $16-24$ jam \\
Daya sebar & $12-14 \mathrm{~m}^{2} / 1$ \\
\hline
\end{tabular}

\section{G. Pengaruh Perbedaan Perbandingan Damar/Terpentin/Minyak Kemiri terhadap Waktu Kering Pernis}

Prosedur kerja pada pengamatan waktu kering pernis dimulai dengan melarutkan damar dalam terpentin dan kemudian diikuti dengan penambahan minyak kemiri ke campuran sehingga diperoleh pernis. Pernis dilaburkan ke sampel kayu dengan berat labur yang sama untuk tiap sampel dan pelaburan hanya dilakukan satu kali. Pengamatan dilakukan terhadap permukaan sampel kayu dengan 
cara menyentuh dengan permukaan jari jempol. Pengamatan dilakukan untuk mengetahui waktu kering sentuh saja. Sebagai pembanding digunakan pernis komersil merek BOYO. Hasil pengamatan ditampilkan pada Tabel 7.

Tabel 7. Waktu Kering Sentuh Pernis yang Dibuat dari Campuran Damar, Terpentin dan Minyak Kemiri

\begin{tabular}{cccccc}
\hline No & Pernis & \multicolumn{3}{c}{ Jumlah Bahan $(\mathrm{ml})$} & Waktu Kering (Menit) \\
\cline { 3 - 5 } & & Damar & Terpentin & Minyak kemiri & \\
\hline 1 & A & 30 & 70 & 30 & 30 \\
2 & B & 30 & 70 & 35 & 40 \\
3 & C & 30 & 70 & 40 & 70 \\
4 & D & 30 & 70 & 45 & 90 \\
5 & E & 30 & 70 & 50 & 120 \\
6 & F & 30 & 70 & 55 & 150 \\
\hline
\end{tabular}

Berdasarkan Tabel 7, maka dapat disimpulkan bahwa perlakuan terpilih adalah pernis A dengan campuran $30 \mathrm{ml}$ damar : $70 \mathrm{ml}$ terpentin dan $30 \mathrm{ml}$ minyak kemiri dikarenakan waktu kering yang dibutuhkan pada campuran ini berada pada rentang waktu kering persil komersil yaitu kisaran 15 sampai 30 menit. Jika perbandingan antara volume damar : volume terpentin : volume minyak kemiri tersebut dikonversi menjadi persen maka perbandingannya adalah $23 \%$ damar : $54 \%$ terpentin : $23 \%$ minyak kemiri.

\section{H. Pengaruh Pemanasan Minyak Kemiri terhadap Waktu Kering Pernis}

Sifat minyak kemiri berubah jika dipanaskan antara lain viskositasnya akan menurun. Meningkatnya suhu pengepresan pada biji kemiri menghasilkan rendemen minyak yang semakin berkurang. Seiring dengan meningkatnya suhu pemanasan maka kadar air dalam biji kemiri semakin berkurang. Berkurangnya kadar air dalam biji menyebabkan partikel biji kemiri menjadi keras sehingga minyak sulit ke luar (Estrada et al., 2007 ; Wiyono, 1995).

Pada penelitian ini minyak kemiri terlebih dahulu dipanaskan pada suhu $110^{\circ} \mathrm{C}$ selama 10 menit. Minyak yang telah dipanaskan kemudian baru dimasukkan ke larutan campuran damar dan terpentin sehingga diperoleh pernis yang siap diujicobakan pada sampel kayu. Hasil pengamatan terhadap waktu kering sentuh ditampilkan pada Tabel 8.

Tabel 8. Lama Waktu Kering Awal Pernis dari Campuran Damar, Terpentin dan Minyak Kemiri yang Dipanaskan pada Suhu $110^{\circ} \mathrm{C}$ Selama 10 Menit

\begin{tabular}{ccc}
\hline No & Perbandingan (Damar: Terpentin: Minyak Kemiri) & Waktu Kering (menit) \\
\hline 1 & $30: 70: 30$ & 15 \\
2 & $30: 70: 35$ & 15 \\
3 & $30: 70: 40$ & 15 \\
\hline
\end{tabular}

Berdasarkan Tabel 7 dan 8 di atas, terlihat bahwa pemanasan minyak kemiri berpengaruh terhadap waktu kering pernis, namun waktu kering yang dihasilkan tetap pada angka kisaran waktu pengeringan pernis komersil yaitu 15 sampai 30 menit sehingga pemanasan minyak kemiri tidak disarankan untuk dilakukan pada pembuatan pernis. Formulasi campuran minyak kemiri sebesar 30, 35 dan $40 \%$ pada pernis membutuhkan waktu pengeringan yang sama yaitu sebesar 15 menit, sedangkan pada minyak kemiri tanpa pemanasan, campuran minyak kemiri sebesar 30, 35 dan 40\% pada pernis membutuhkan waktu kering selama 30, 40 dan 70 menit seperti Tabel 7.

\section{Karakteristik Pernis dari Komposisi Terpilih}

Dari data yang ditampilkan pada Tabel 8, maka dapat disimpulkan bahwa komposisi pernis yang optimum pada perbandingan damar : terpentin : minyak kemiri adalah $30: 70: 30$ tanpa minyak kemiri dipanaskan. Pemanasan memerlukan biaya sedangkan waktu kering pernis $30: 70: 30$ telah dapat menghasilkan pernis yang dapat mengering dalam waktu sama dengan waktu kering pernis 
komersil merek BOYO. Perbandingan damar : terpentin , 30 : 70 merupakan perbandingan dengan kelarutan damar tertinggi dalam terpentin. Minyak kemiri dapat ditambahkan lebih banyak namun pada perbandingan $30: 70: 30$ telah cukup untuk memperoleh pernis yang cepat mengering dan sebaliknya jika dengan jumlah dibawah 30 menyebabkan pengeringan berlangsung lebih lama. Adapun karakteristik pernis sebagai komposisi terpilih ditampilkan pada Tabel 9 dan kayu dengan penambahan pernis dan tanpa pernis terlihat pada Gambar 4.
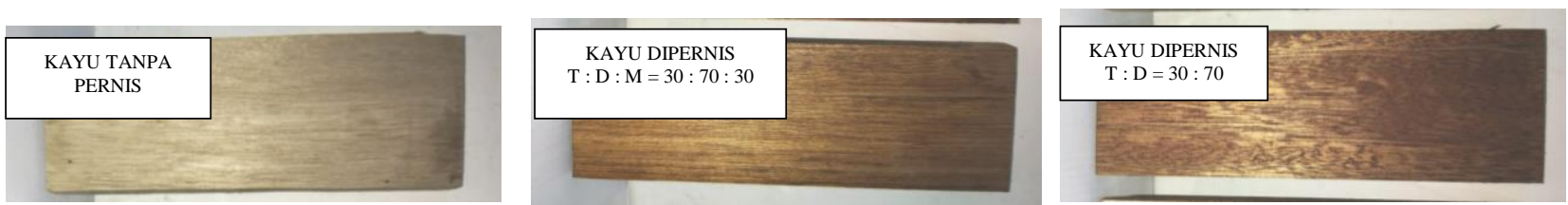

Gambar 4. Kayu tanpa dipernis dan dipernis.

$\mathrm{T}=$ Terpentin; $\mathrm{D}=$ Damar; $\mathrm{M}=$ Minyak Kemiri

Tabel 9. Karakteristik Pernis Komposisi Terpilih Hasil Penelitian dibanding SNI

\begin{tabular}{clll}
\hline No & Parameter & Hasil Pengamatan & SNI \\
\hline 1 & Berat jenis & 0,92 & $0,92-0,94$ \\
2 & Warna & Kuning bening & Coklat muda bening \\
3 & Lama Pengeringan & 30 menit & $120-240$ menit \\
4 & Kekentalan & $6,8 \mathrm{cP}$ & $6-7 \mathrm{cP}$ \\
5 & Kekuatan Geser & $5,3 \mathrm{~kg} / \mathrm{cm}^{2}$ & $5-7 \mathrm{~kg} / \mathrm{cm}^{2}$ \\
\hline
\end{tabular}

Berdasarkan Tabel 9, terlihat perbedaan karakteristik pernis hasil pengamatan dengan SNI pada parameter lama pengeringan. Pernis hasil penelitian lebih cepat mengering dibanding SNI, hal ini diduga karena perbedaan persentasenya campuran penyusun dari pernis. Selanjutnya, pernis terpilih dari hasil pengujian, diuji juga sifatnya dan dibandingkan dengan pernis komersil dimana hasilnya dapat dilihat pada Tabel 10.

Tabel 10. Pengamatan sifat pernis hasil penelitian dari komposisi terpilih dibanding pernis komersil

\begin{tabular}{llll}
\hline No & Pengamatan & Pernis Hasil Penelitian & Pernis Komersil \\
\hline 1 & Lama pengeringan & 30 menit & 30 menit \\
2 & Daya kilap & Kurang mengkilap & Agak mengkilap \\
3 & Kesan raba & Kesat & Kesat \\
4 & Terpapar oksigen udara & Mengental & Agak Mengental \\
5 & Sifat pelaburan & Merata & Merata \\
6 & Akibat aplikasi pada kayu cerah & Agak gelap & Sedikit terang \\
7 & Jumlah terpakai tiap m $^{2}$ & $140-150 \mathrm{~g}$ & $140-158 \mathrm{~g}$ \\
\hline
\end{tabular}

Berdasarkan Tabel 10, terlihat perbandingan antara pernis hasil penelitian dan pernis komersil. Dari data, tidak terdapat perbedaan yang signifikan antara pernis hasil penelitian dengan pernis komersil yang digunakan sehingga dapat disimpulkan bahwa pernis hasil penelitian dapat dipergunakan seperti penggunaan pernis komersil pada umumnya. Perbedaan hanya terlihat pada aplikasi pernis pada kayu cerah yang menghasilkan wana agak gelap pada pernis hasil penelitian dan sedikit terang pada pernis komersil. Perbedaan warna ini diduga karena adanya tambahan pigmen ataupun zat aditif lainnya pada pernis komersil (Dahlian et al., 2003).

\section{KESIMPULAN}

Dari hasil penelitian dapat disimpulkan bahwa di Pesisir Selatan didapatkan jenis damar mata kucing dan damar batu. Karakteristik damar mata kucing yang didapatkan antara lain warna kuning bening, titik leleh $71{ }^{0} \mathrm{C}$, densiti $0,68 \mathrm{~g} / \mathrm{cm}$ dan kehilangan berat suhu $105{ }^{0} \mathrm{C} 18 \mathrm{jam} 0,84 \%$. Damar matakucing diaplikasikan dalam pembuatan pernis. Komposisi terpilih pernis yang dihasilkan dengan waktu pengeringan yang sama dengan pernis komersil adalah 23\% damar, 54\% terpentin dan 23\% minyak kemiri. 


\section{UCAPAN TERIMAKASIH}

Penelitian ini didanai oleh DIPA Fakultas Teknologi Pertanian Universitas Andalas Tahun 2019. Peneliti menyampaikan terimakasih atas dukungan pendanaan dan fasilitas yang telah diberikan.

\section{DAFTAR PUSTAKA}

[BPS] Badan Pusat Statistik. 2019. Produksi Damar Provinsi Sumatera Barat. Jakarta: BPS.

[BSN] Badan Standardisasi Nasional. 2012. Damar Bagian I: Klasifikasi dan Persyaratan Mutu Berdasarkan Uji Visual SNI 2900-1-2012. Jakarta: BSN

Abdulgani M., 2002. Gondorukem dan Terpentin di Indonesia. Semarang: Perum Perhutani Unit I Jawa Tengah.

Abdulmalik, Nadia, Khairunnisa. 2016. Pengaruh Komposisi Damar Mata Kucing pada Pembuatan Lilin Batik Terhadap Kualitas Pewarnaan Hasil Pembatikan. Teknoin. 22 (4): 252-260.

Arianti DO, Idham M., Zainal S. 2018. Pemanfaatan Getah Damar oleh Masyarakat di Kelurahan Kedamin Hulu Kecamatan Putussibau Selatan Kabupaten Kapuas Hulu. Jurnal Hutan Lestari. 6 (3): 464-472.

BBSRC. 2004. Business; The Quarterly Magazine of the Biotechnology and Biologycal Sciences Research Council. [http:www.bbsrc.ac.uk diakses 2 Agustus 2020].

Dahlian E, Hartoyo, Yusnita. 2003. Optimasi Pembuatan Pernis Damar (Shorea javanica). Buletin Penelitian Hasil Hutan. 21(1): 23-30.

Darmawan S. 2006. Pembuatan Minyak Kemiri dan Pemurniannya dengan Arang Aktif dan Bentonit. Jurnal Penelitian Hasil Hutan. 24(5): 413-423.

Estrada F, Gusmao R., Mudjijati, Indraswati N. Pengambilan Minyak Kemiri dengan Cara Pengepresan dan Dilanjutkan Ekstraksi Cake Oil. Widya Teknik. 6 (2): 121-130.

Edriana E, Dahlian E, Sumadiwangsa ES. 2018. Teknik Pembuatan Pernis dari Damar untuk Usaha Kecil. Jurnal Penelitian Hasil Hutan. 22(4): 205-213.

Kartika IA., Pratiwi DF. 2018. Characteristic of Particle Board from Bamboo with Damar Resin as Adhesive. Jurnal Teknologi Industri Pertanian. 28 (2):127-137.

Karyono OK, Sumadiwangsa S, Poernama BM. 1996. An Analysis on the Production and Economic of Resin in West Sumatera. Buletin Penelirian Hasil Hutan. 14(9): 355-365.

Kasim A., Malrianti Y, Syukri D, Derosya V. 2019. GC-MS Screening of Valuable Volatile Compounds in the Waste of Uncaria gambir. Annals of Biology. 35(2): 242-245.

Kuspradini H, Rosamah E, Sukaton E, Arung ET, Kusuma IW. 2016. Pengenalan Jenis Getah; GumLateks- Resin. Samarinda: Mulawarman University Press.

Malrianti Y, Kasim A, Novelina. 2019. Tannins and Catechins Content of Gambier (Uncaria gambier Roxb) in Relation with Adhesive Qualities and Bonding Strength of Cold Setting Glue. International Journal of Advanced Research. 6(12): 622-627.

Mulyono N, Wijaya CH, Fardiaz D, Rahayu WS. 2012. Identifikasi Komponen Kimia Damar Mata Kucing (Shorea Javanica) dengan Metode Pirolisis-GC/MS. Jurnal Natur Indonesia. 14(2): 155159.

Saxena NP. 2010. Objective Botany. India: Krisna Praskashan Media (P) Ltd.

Suranto Y. 2018. Karakter dan Kualitas Gondorukem Kuna Hasil Penemuan di Pemukiman Pecinan Kutoarjo Kabupaten Purworejo. Jurnal Konservasi Cagar Budaya. 12(2): 47-60.

Wiyono B. 1995. Pengolahan Minyak Kemiri dengan Cara Pelarutan dan Pengempaan. Jurnal Penelitian Hasil Hutan. 13(03): 110-117.

Wiyono B, Silitonga T. 2001. Pengaruh Jenis Pelarut dan Kualitas Damar terhadap Rendemen dan Sifat Fisiko-Kimia Damar yang Dimurnikan. Bul. Pen. Has. Hut. 19(2): 103-115. 